The Ruins of Experience 
This page intentionally left blank 


\title{
The Ruins of Experience
}

\section{Scotland's "Romantick" Highlands} and the Birth of the Modern Witness

\author{
MATTHEW WICKMAN
}

\section{PENN}

University of Pennsylvania Press

Philadelphia 
Copyright $\odot 2007$ University of Pennsylvania Press

All rights reserved

Printed in the United States of America on acid-free paper

10987654321

Published by

University of Pennsylvania Press

Philadelphia, Pennsylvania 19104-4112

A Cataloging-in-Publication record is available from the Library of Congress

ISBN-13: 978-0-8122-3971-3

ISBN-10: 0-8122-3971-7 
For Kerry, Hadley, and Elena, the epitome of experience 
This page intentionally left blank 